\title{
Isoprene emission rates and fluxes measured above a Mediterranean oak (Quercus pubescens) forest
}

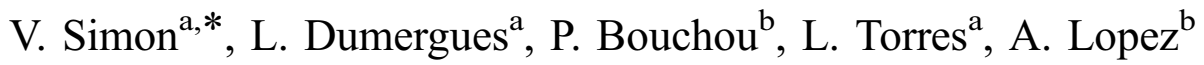 \\ ${ }^{a}$ Laboratoire Chimie Energie et Environnement, Ecole Nationale Supérieure des Ingénieurs en Arts Chimiques et \\ Technologiques de Toulouse, 118, route de Narbonne, 31077 Toulouse Cedex, France \\ ${ }^{\mathrm{b}}$ Laboratoire d'Aérologie, UMR UPS/CNRS 5560, Observatoire Midi-Pyrénées, 14 avenue Edouard Belin, \\ 31400 Toulouse, France
}

\begin{abstract}
The present work, carried out as part of the European fiEld experimentS to COnstrain Models of atmospheric Pollution and Transport of Emissions project (ESCOMPTE), brings a new contribution to the inventory of the main natural hydrocarbons sources that are liable to participate in the production of ozone. The measurement campaign was conducted in Montmeyan, a site close to Marseilles (France), with the aim of quantifying the terpenic emission pattern and the behaviour of Quercus pubescens, an important Mediterranean tree species.

Biogenic emissions by $Q$. pubescens were determined by the enclosure of an intact branch of this tree in a Teflon cuvette. The total monoterpenic emission rates thus recorded were found to reach maximum values ranged between 40 and $350 \mu \mathrm{g} \mathrm{g}_{\text {Dry Weight }}^{-1} \mathrm{~h}^{-1}$. Emissions were correlated strongly with leaf temperature and Photosynthetic Active Radiation (PAR). The fluxes were also determined by extrapolating the results of the enclosure method and by using aerodynamic gradient method. They reach around $73 \mathrm{mg} \mathrm{m}^{-2} \mathrm{~h}^{-1}$ with the first method and $55 \mathrm{mg} \mathrm{m}^{-2} \mathrm{~h}^{-1}$ with the second one. The obtained values fit with a maximal ratio of 2 .
\end{abstract}

Keywords: Biogenic VOC emissions; Mediterranean vegetation; Isoprene; Cuvette; Flux; Aerodynamic gradient method; Quercus pubescens

* Corresponding author. Tel.: +33 5628857 18; fax: +33 562885600 .

E-mail address: valerie.simon@ensiacet.fr (V. Simon). 


\section{Introduction}

Many volatile organic compounds (VOCs) are emitted from vegetation. Emissions of isoprene and monoterpenes have been studied extensively because of their role in the photochemistry and the formation of tropospheric ozone and their indirect contribution to the global warming (Fehsenfeld et al., 1992).

The nature and intensity of terpenic emissions vary according to the vegetal species. Such emissions depend on the vegetal physiological activity, leaves temperature and PAR (Yokouchi and Ambe, 1984; Steinbrecher et al., 1991; Simon et al., 1994; Staudt and Seufert, 1995; Kesselmeier et al., 1997; Schuh et al., 1997; Kim, 2001; Sabillon and Cremades, 2001; Shao et al., 2001).

Our study was realized in frame of the fiEld experimentS to COnstrain Models of atmospheric Pollution and Transport of Emissions (ESCOMPTE) project (Cros et al., 2004) whose zone of study is based on the site of Berre-Marseilles because mainly of the high frequency of the episodes of pollution. The hot and sunny Mediterranean climate, the abundance of high VOC-emitting vegetation and the presence of two poles of important anthropic emissions with the Marseilles agglomeration (1.2 million inhabitants) and the industrial park of the pond of Berre associated with favorable weather conditions are the origin of the air pollution of the area. The aim of the project is the physicochemical modeling of the local tropospheric processes. This point requires the establishment of emission inventories in particular concerning the biogenic emissions by the vegetable sources. Many studies have already been realized in the frame of the Biogenic Emissions in the Mediterranean Area project (BEMA) (Ciccioli et al., 1997; Kesselmeier et al., 1997; Owen et al., 1997; Seufert et al., 1997; Staudt et al., 1997; Steinbrecher et al., 1997; Street et al., 1997; Kesselmeier et al., 1998; Darmais et al., 2000). The high variability of normalized emission rate throughout the year and depending on the geographical measurement point has led us to complete the known measurements. Quercus pubescens was studied because of its large coverage (first for the forest occupation percentage) (www.ifn.fr) and its high isoprene emission potential.

Vertical fluxes, from the vegetation-atmosphere interface, were measured by an aerodynamic method and then compared to those deduced from emission rates measured in cuvette.

\section{Experimental}

\subsection{Characterization of the campaign site}

The Montmeyan sampling site $\left(43^{\circ} 39^{\prime} 18^{\prime \prime} \mathrm{N}-06^{\circ} 05^{\prime} 55^{\prime \prime} \mathrm{E}\right)$ is located in a middle of a communal forest at around $70 \mathrm{~km}$ in the North East of Marseilles (Fig. 1). The forest, spreading on several kilometers, is essentially composed by $Q$. pubescens from 6 to $12 \mathrm{~m}$ height. The canopy is relatively dense and homogeneous. The herbaceous under layer is scattered.

The site leaf area index (LAI) is approximately $2.3 \mathrm{~m}^{2} \mathrm{~m}^{-2}$ (personal communication of CEMAGREF) which represents about $309 \mathrm{~g} \mathrm{~m}^{-2}$ taking in consideration an average leaf 


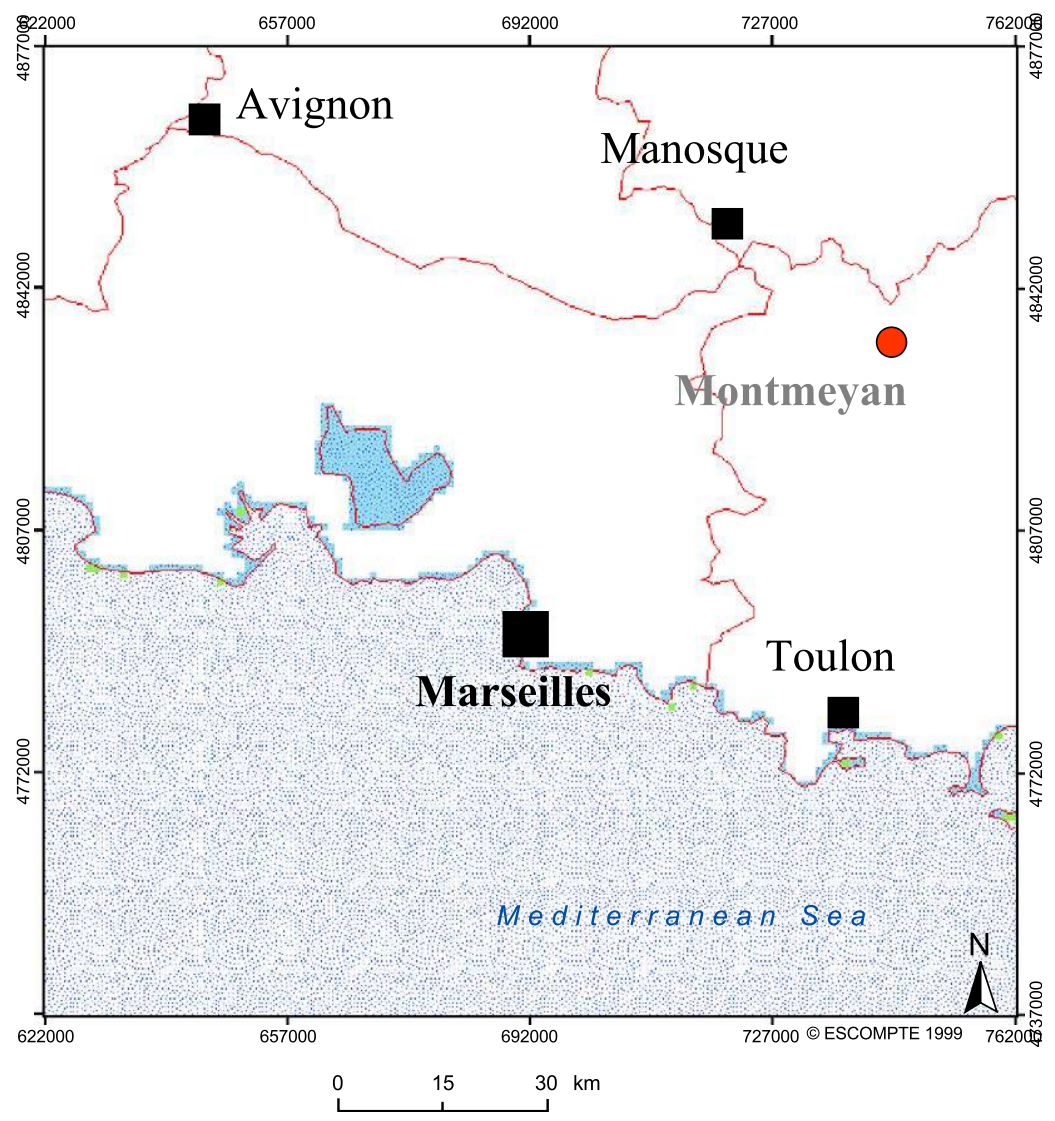

Fig. 1. Localisation of Montmeyan.

mass area measured of $134.3 \mathrm{~g} \mathrm{~m}_{\text {leaf }}^{-2}$. Q. pubescens is one of the most representative species of Provence-Alpes-Côte d'Azur (PACA) as it represents a coverage of $23.7 \%$ (www.ifn.fr).

From the 14th to 23rd June, meteorological measurements were conducted from a tower equipped with different sensors (Table 1) and describe the thermodynamic

Table 1

Instrumentation

\begin{tabular}{ll}
\hline Parameter & Instrument \\
\hline $\begin{array}{l}\text { Air temperature at the top of tower } \\
\text { Air temperature at cuvette's height and }\end{array}$ & $\begin{array}{l}\text { Thermocouple (Cu-Const) in ventilated shelters (Laboratory) } \\
\text { Thermocouple (OMEGA-France) }\end{array}$ \\
Net flux radiation & \\
Incident visible flux & Thermopile (Swissteco) \\
Photosynthetic active radiation & Thermopile (Eppley) \\
$\mathrm{CO}_{2}$ inside and outside the cuvette & Probe (HTR2-PPSystems-France) \\
Humidity inside and outside the cuvette & WMA2 (PPSystems-France) \\
\hline
\end{tabular}


conditions of the experiment. During the campaign, the diurnal maxima of air temperature increased from 20 to $30{ }^{\circ} \mathrm{C}$ and the maximum amplitude of the diurnal variation was $8{ }^{\circ} \mathrm{C}$. The variation of the net radiation shows that the period was characteristic of fine weather with a significant net energy at noon $\left(700 \mathrm{~W} \mathrm{~m}^{-2}\right)$ for the entire period. The area was mainly submitted to NW and SE wind patterns, but since the site is rural, it was not directly influenced by urban or industrial pollution.

\subsection{Experimental methods}

\subsubsection{Emission rates measurements from cuvette}

Two cuvettes were mounted side by side at a height of $10 \mathrm{~m}$ on a scaffold erected in the vicinity of $Q$. pubescens. An intact Quercus branch located at middle height in the canopy was enclosed in the cuvette which was flushed with ambient air (Kesselmeier et al., 1996). The mass of dry leaf on these branches was $10.25 \mathrm{~g}$. The other empty cuvette was used as a reference.

The cuvette was made of a light metallic frame holding a cylindric teflon bag (diameter: $25 \mathrm{~cm}$; height $42 \mathrm{~cm}$; volume: 21 1). Teflon films (FEP) are appropriate due to their transparence to the solar spectrum (300-900 nm) (Schäfer et al., 1992). A stream of ambient air was passed through the cuvette at a flow rate of $11 \mathrm{Nl} \mathrm{min}{ }^{-1}$. The air inside the cuvette was also homogenezed by a Teflon fan installed at its top. The air samples to be analyzed were collected at the exit of the cuvette. Once the branches were enclosed in the cuvettes, 4 days was allowed before the beginning of the measurements in order to minimize the effects of a possible stress of the branch as a consequence of its confinement.

The cuvettes were equipped with probes allowing the measurement of air and leaf temperature (precision fire wire thermocouples, OMEGA-France), relative humidity ratio and Photosynthetic Active Radiation (PAR) (HTR2-PPSystems-France). The $\mathrm{CO}_{2}$ concentrations were also measured (WMA2-PPSystems-France). All parameters were measured both inside and outside the cuvette. All data were collected every $5 \mathrm{~min}$ in a central acquisition device (AOIP-SA32). The emission rates were obtained from the difference between the concentrations recorded inside and outside the cuvette (Luchetta, 1999).

\subsubsection{Vertical flux measurements from vegetation/atmosphere interface}

2.2.2.1. From the cuvette method. Vertical isoprene fluxes $\left(F: \mu \mathrm{g} \mathrm{m}^{-2} \mathrm{~h}^{-1}\right)$ can be approximated from emission rates (ER: $\mu \mathrm{g} \mathrm{g}_{\mathrm{DW}}{ }^{-1} \mathrm{~h}^{-1}$ ), Leaf Area Index (LAI: $\mathrm{m}^{2} \mathrm{~m}^{-2}$ ) and foliar mass area $(\mu: \mathrm{g})$ in hypothesizing a transfer matter intensity, at the vegetationatmosphere interface, sufficient to maintain the matter conservation. This assumption is verified during the daytime, when the turbulent fluxes are higher.

$$
F=E R \cdot L A I \cdot \mu
$$

In these conditions, the fluxes evolution at the vegetation-atmosphere border are similar to those of emission rates.

2.2.2.2. From the aerodynamic gradient method. At the atmosphere-biosphere interface, the vertical fluxes of isoprene can be calculated by the aerodynamic gradient method. The 
measurement of the vertical gradient concentration above the canopy is necessary to apply this method that consists in evaluating the vertical flux of a scalar $X$ with the relation:

$$
F_{x}=\overline{w^{\prime} x^{\prime}}=-K_{x}(z) \frac{\partial \bar{X}}{\partial z}
$$

where $F_{x}$ is the vertical flux of the scalar $X, K_{x}(z)\left(\mathrm{m}^{2} \mathrm{~s}^{-1}\right)$ is the turbulent exchange coefficient of the scalar, $\partial X / \partial z$ is the vertical gradient of $X$ (in this case, the isoprene gradient concentration between 12.5 and $15 \mathrm{~m}$ ) (Garland,1974).

It is generally admitted that the turbulent transport of a scalar is similar to the turbulent transport of heat (Stull, 1988; Monteith and Unsworth, 1990). This hypothesis allows to consider the isoprene exchange coefficient as the sensible heat exchange coefficient $\left(K_{\theta}\right)$ determined applying the Monin-Obukov similarity theory (Monin and Obukhov, 1954).

This similarity theory requires the introduction of characteristic parameters of boundary surface layer (roughness length $z_{0}$, displacement distance $d$ ) and the parameterisation of the application area with different specific scales of the atmosphere stability (friction velocity $u^{*}$, Monin-Obukov length $L$ ). Therefore, the dimensionless scalar gradient $\Phi_{x}(\xi)$ are defined and the turbulent exchange coefficients are computed.

Theoretically, we have

$$
\Phi_{\theta}(\xi)=\frac{k z}{\theta^{*}} \frac{\partial \bar{\theta}}{\partial z}
$$

and

$$
\theta^{*}=-\frac{\overline{w^{\prime} \theta^{\prime}}}{u^{*}}
$$

where $w^{\prime} \theta^{\prime}$ is the covariance of the vertical wind velocity and the temperature and $u^{*}$ the friction velocity calculated with the turbulent vertical flux of momentum. $K_{\theta}$ is derived from the relations (2), (3) and (4)

$$
K_{\theta}=\frac{k u^{*} z}{\Phi_{\theta}(\xi)} \approx K_{\text {iso }}
$$

$\Phi_{\theta}$ is a dimensionless temperature gradient, $\xi$ is the stability parameter defined by $\xi=((z-d) /(L)), k$ is the von Karman constant equal to $0.4, K_{\text {iso }}$ is the isoprene vertical turbulent exchange coefficient and $L=\left(\left(u^{* 2}\right)\left(k\left(g / T_{0}\right) \theta^{*}\right)\right)$ is the Monin-Obukov length (Monin and Obukhov, 1954). The zero-plane displacement height $d$ represents an imaginary surface where the property fluxes become zero and where at $d+z_{0}$, the wind speed equals zero. To a rough approximation, $d$ is in the range $0.6 h$ to $0.7 h$ where $h$ is the mean height vegetation estimated at $12 \mathrm{~m}$. In our application of the gradient profile method, we assumed that $d=0.7 \mathrm{~h}$. This yields a non-negligible $d=8.4 \mathrm{~m}$.

During the day time, the direct application of this method is very sensitive because the vertical temperature gradients considered in relation (3) are very low and the estimation of the exchange coefficient becomes very imprecise. Consequently, we use the empirical form of dimensionless gradient $\left(\Phi_{\theta}(\xi)\right)$ established by many authors (Dyer and 
Hicks, 1970; Webb, 1970; Businger et al., 1971). In the present study, the expressions of Businger et al. (1971) are employed:

$$
\begin{aligned}
& \Phi_{\theta}(\xi)=0.74+4.7 \xi \quad \text { Stable period }(\xi>0) \\
& \Phi_{\theta}(\xi)=1 \quad \text { Neutral period }(\xi=0) \\
& \Phi_{\theta}(\xi)=0.74(1-9 \xi)^{-1 / 2} \quad \text { Instable period }(\xi<0)
\end{aligned}
$$

Practically, the determination of the isoprene vertical flux above the canopy with the aerodynamic gradient method requires the measurement of the isoprene concentration at different levels and the measurement of vertical fluxes of momentum and sensible heat.

Energetic fluxes have been determined by Eddy correlation method (Baldochi et al., 1988; Stull, 1988) which defines the vertical turbulent flux as the mean covariance between the fluctuation of vertical wind velocity $(w)$ and the considered scalar ( $T$ for sensible heat and $u$ for flux of momentum) over samples of $30 \mathrm{~min}$. Therefore, the necessary parameters to apply this method are the fluctuations of $w, u$ and $T$ which are respectively measured with a sonic anemometer (Gill) and a platinum fast sensor.

\subsection{Sampling and analysis of terpenes}

Biogenic Volatile Organic Compounds were sampled on Tenax TA (60-80 mesh) cartridges every $45 \mathrm{~min}$ to $2 \mathrm{~h}$. The air sampled volume varied between 0.1 and $1.51 \mathrm{in}$ order to optimize the ratio signal/threshold without exceeding the breakthrough volumes of each compounds. VOCs trapped on Tenax TA were analysed in situ using a Perkin Elmer Autosystem XL-FID gas chromatograph with a CP-Wax column $(60 \mathrm{~m} * 0.32 \mathrm{~mm}$ id*1.2 $\mu \mathrm{m}$, Chrompack) equipped with an automatic sample device (TurboMatrix, ATD, $\mathrm{PE}$ ). The initial oven temperature of $35^{\circ} \mathrm{C}$ was maintained for $4 \mathrm{~min}$, increased to $180{ }^{\circ} \mathrm{C}$ at $5{ }^{\circ} \mathrm{C} \mathrm{min}{ }^{-1}$ and maintained for $30 \mathrm{~min}$. Other analytical parameters were: detector temperature $\left(250{ }^{\circ} \mathrm{C}\right)$, transfert line temperature $\left(230{ }^{\circ} \mathrm{C}\right)$, flow rate $\mathrm{He}\left(1.4 \mathrm{ml} \mathrm{min}{ }^{-1}\right.$ at 30 $\left.{ }^{\circ} \mathrm{C}\right), \mathrm{H}_{2}$ flow rate $\left(45 \mathrm{ml} \mathrm{min}^{-1}\right)$, air flow rate $\left(450 \mathrm{ml} \mathrm{min}{ }^{-1}\right)$. The detection limit for isoprene is $10 \mathrm{pptv}$ considering an air sampling volume of 11 , with a level of analytical precision better than 5\% (Luchetta, 1999).

The identification of VOCs was based on GC peak retention time matching those of authentic standards in parallel with a GC/MS (CP 4020 Chrompack-HP 5890-HP 5971A) for optimum peak identification. The calibration was carried out at the laboratory by using permeation cells prepared from authentic standards (Extrasynthèse, France). The calibration factor for isoprene used for calculation of concentrations was checked periodically throughout the analysis period.

Intercomparison experiments performed during field campaigns for the BEMA project (Larsen et al., 1997; Kesselmeier et al., 1998) and the ESCOMPTE project indicated that the sampling and analytical system used for this study is an appropriate tool to measure VOC emission rates from vegetation. Further uncertainties could arise from the natural variability between branches of the same tree. However, as trees and branches were selected as being visually representative of the species and in reasonable health, it was assumed that emission rate measurements would also be representative (Owen et al., 
2001). An overall sampling and analytical uncertainty of around $30 \%$ is associated with emission rate measurements made with this system (Dumergues, 2003).

\section{Results}

\subsection{Q. pubescens emission rates}

The main terpens emitted by $Q$. pubescens and identified in the cuvette are: isoprene, alpha-pinene, beta-pinene, sabinene, $\Delta 3$-carene, myrcene, limonene and 1.8 -cineole. The isoprene emission rate is at least 250 times more important than the one of the total monoterpenes. Therefore, only isoprene results are presented.

The isoprene emission was observed during all the measurement period but only the results of the least (17th June) and the most (25th June) favorable day for terpenic emissions are presented in Figs. 2 and 3. They show maximal diurnal emission between 40 and $350 \mu \mathrm{g} \mathrm{g}_{\mathrm{dw}}^{-1} \mathrm{~h}^{-1}$, non-existent night emission and the evolution of micrometeorological and physiological parameters.

Even if a lot of factors influence isoprene emission rates, they depend on leaf temperature over the whole range of conditions encountered during the campaign (12-40 ${ }^{\circ} \mathrm{C}$ ) (Fig. 4). No-drop off in isoprene emission rate was observed at around $40{ }^{\circ} \mathrm{C}$. However, several reports have shown that the isoprene emissions decrease at high temperatures for other tree species (Tingey et al., 1987; Monson et al., 1992).

The algorithm model developed by Guenther et al. (1991), rearranged by Guenther et al. (1993), was compared with isoprene emission rates measured in $Q$. pubescens forest. The Guenther model estimates isoprene emission rates as

$$
I=I_{\mathrm{S}} C_{\mathrm{T}} C_{\mathrm{L}}
$$

where $I$ is the emission rate at temperature $T$ and PAR flux $L$, and $I_{\mathrm{s}}$ is the isoprene emission rate at standard conditions (temperature $=30{ }^{\circ} \mathrm{C}$; PAR flux $=1000 \mu \mathrm{mol} \mathrm{m}{ }^{-2} \mathrm{~s}^{-1}$ ). The light correction factor $C_{\mathrm{L}}$ is estimated from the following equation

$$
C_{\mathrm{L}}=\frac{\alpha C_{\mathrm{L} 1} L}{\sqrt{1+\alpha^{2} L^{2}}}
$$

where $L$ is the PAR flux, $\alpha(=0.0027)$ and $C_{\mathrm{L} 1}(=1.066)$ are empirical coefficients derived from emission rate measurements with several vegetation species.

The leaf temperature correction factor $C_{\mathrm{T}}$ is given by

$$
C_{\mathrm{T}}=\frac{\exp \frac{C_{\mathrm{T} 1}\left(T-T_{\mathrm{S}}\right)}{R T T_{\mathrm{S}}}}{C_{\mathrm{T} 3}+\exp \frac{C_{\mathrm{T} 2}\left(T-T_{\mathrm{M}}\right)}{R T T_{\mathrm{S}}}}
$$

where $R$ is the ideal gas constant $\left(=8.314 \mathrm{~J} \mathrm{~K}^{-1} \mathrm{~mol}^{-1}\right), T$ is the leaf temperature in $\mathrm{K}, T_{\mathrm{s}}$ $(=303 \mathrm{~K})$ is the standard temperature and $T_{\mathrm{M}}(=314 \mathrm{~K}), C_{\mathrm{T} 1}\left(=95.000 \mathrm{~J} \mathrm{~mol}^{-1}\right), C_{\mathrm{T} 2}$ $\left(=230.000 \mathrm{~J} \mathrm{~mol}^{-1}\right)$ and $C_{\mathrm{T} 3}(=0.961)$ are empirical coefficients. 
Foliar temperature $\left({ }^{\circ} \mathrm{C}\right)$

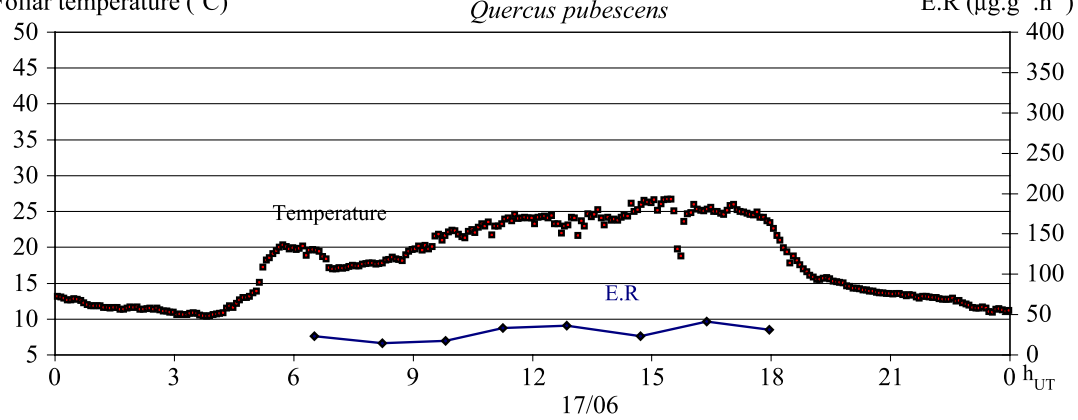

Photosynthetic $\mathrm{CO}_{2}$ assimilation $\left(\mu \mathrm{mol} \cdot \mathrm{mol}^{-1}\right) \quad$ Quercus pubescens $\quad$ E.R $\left(\mu \mathrm{g} \cdot \mathrm{g}^{-1} \cdot \mathrm{h}^{-1}\right)$
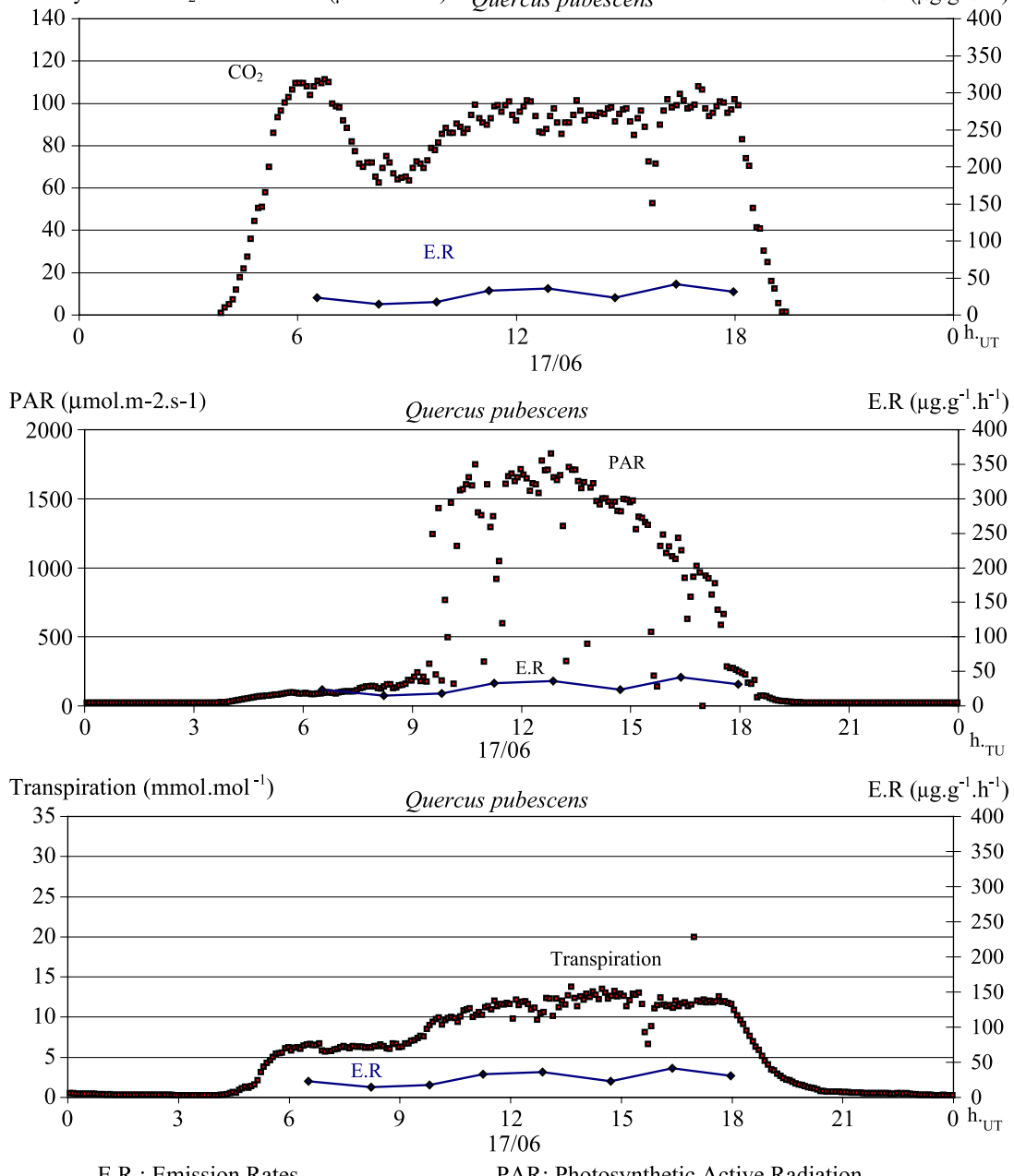

E.R.: Emission Rates

PAR: Photosynthetic Active Radiation

Fig. 2. Evolution of isoprene emission rates, foliar temperature, photosynthetic assimilation, PAR and transpiration (17th June 2001). 


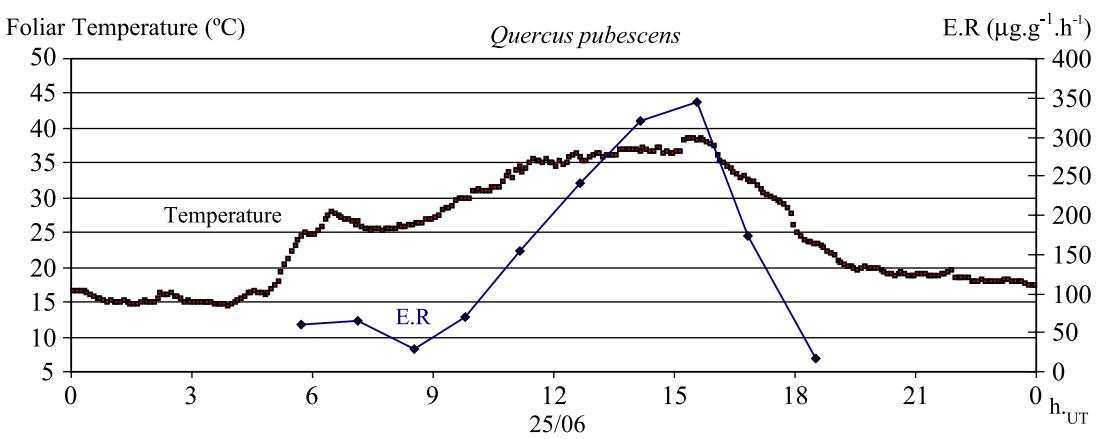

Photosynthetic $\mathrm{CO}_{2}$ assimilation $\left(\mu \mathrm{mol} \mathrm{mol}{ }^{-1}\right)$ Ouercus pubescens $\quad$ E.R $\left(\mu \mathrm{g} \cdot \mathrm{g}^{-1} \cdot \mathrm{h}^{-1}\right)$
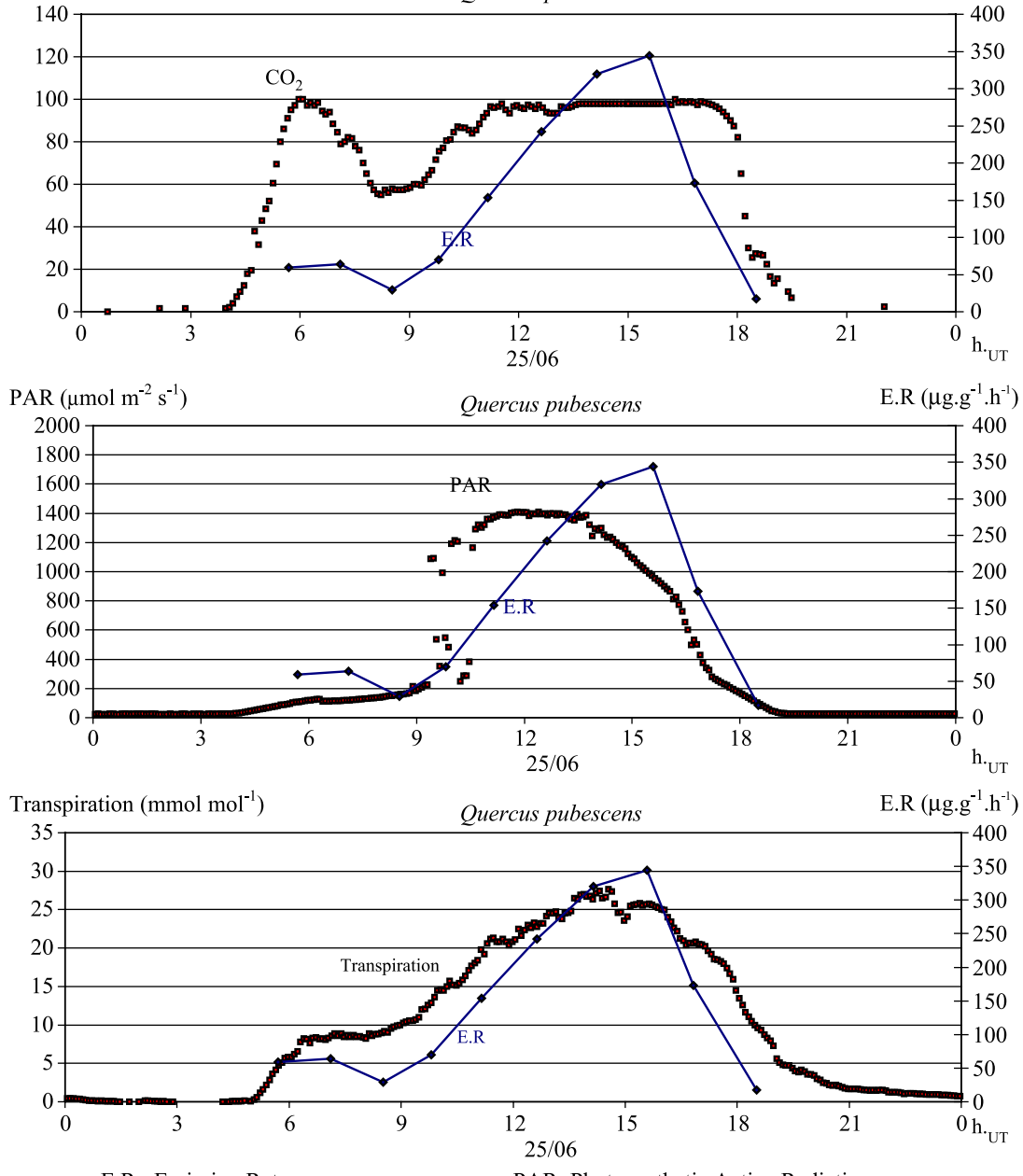

E.R.: Emission Rates

PAR: Photosynthetic Active Radiation

Fig. 3. Evolution of isoprene emission rates, foliar temperature, photosynthetic assimilation, PAR and transpiration (25th June 2001). 


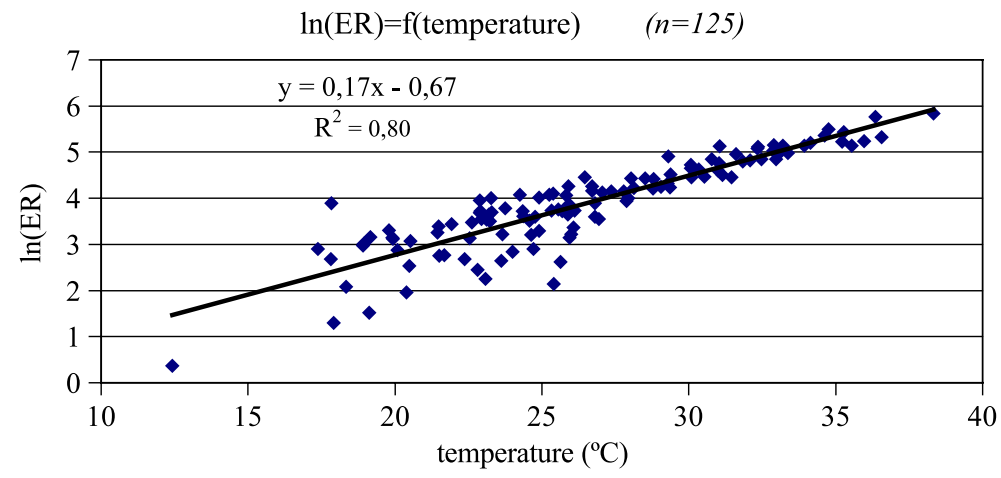

Fig. 4. $\mathrm{Ln}(\mathrm{ER})=f$ (foliar temperature).

These two algorithms are currently the best in representing the emission evolution over short periods. Over longer periods, other corrective factors such as biomass density variation (Owen and Hewitt, 2000), or seasonal normalised emission rate evolution (Pier and McDuffie, 1997; Staudt et al., 2000) can be integrated.

The Guenther model seems to provide realistic isoprene emission rates for $Q$. pubescens. The estimated $I_{\mathrm{S}}$ value is of $134.7 \mu \mathrm{g} \mathrm{g}_{\mathrm{DW}}^{-1} \mathrm{~h}^{-1}$ (Fig. 5). The normalised emission rate obtained is higher than those quoted in literature data (Table 2). A ratio of three exists between our result and the minimal value. These differences could be linked to the different genetic origin of oaks and to seasonal variation (Schnitzler et al.,1997; Staudt et al., 2000).

A significant correlation between isoprenic emission and the foliar transpiration is obtained (Fig. 6). The transpiration profiles depend on the stomatal opening profiles. As demonstrated for other vegetals (Guenther et al., 1991), this result seems to confirm that VOC are emitted from the needle stomata.

\subsection{Fluxes}

\subsubsection{Fluxes from cuvette method}

Isoprene fluxes were determined from emission rates as explained previously (Section 2.2.2). The daily profile evolution is similar for both emission rates and emission fluxes for

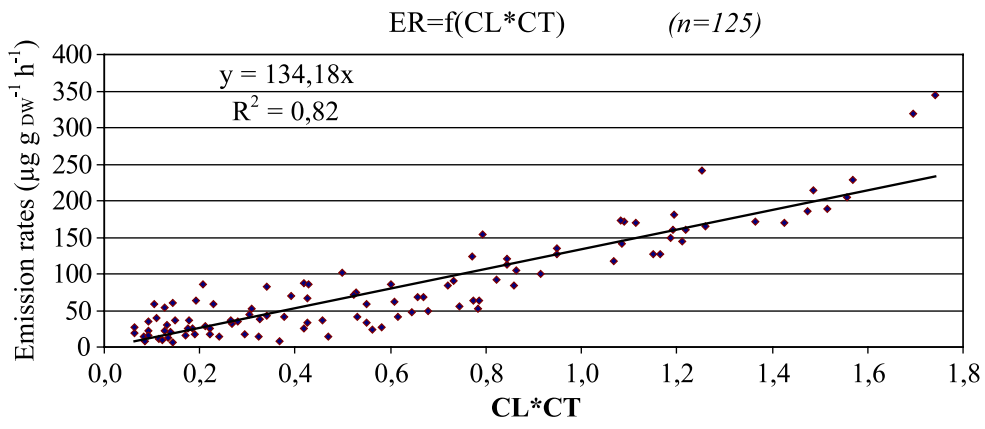

Fig. 5. Application of the Guenther's algorithm. 
Table 2

Bibliographic comparison of $Q$. pubescens emission rates

\begin{tabular}{llll}
\hline $\begin{array}{l}\text { Normalized emission rates } \\
\left(\mu \mathrm{g} \mathrm{g}_{\mathrm{DW}}^{-1} \mathrm{~h}^{-1}\right)\end{array}$ & Place & Period & References \\
\hline 134.7 & Montmeyan, France & June 2001 & Our results \\
75 & Montpellier, France & June 1995 & Owen et al., 1998 \\
92 & Montpellier, France & October 1995 & Owen et al., 1998 \\
90.7 & Castelporziano, Italy & Spring 1994-1995 & Steinbrecher et al., 1997 \\
58.4 & Montpellier, France & May 1995 & Kesselmeier et al., 1998 \\
42 & Montpellier, France & June 1995 & Kesselmeier et al., 1998 \\
48.6 & Montpellier, France & June 1995 & Kesselmeier et al., 1998 \\
60 & & & CORINAIR, 1999 \\
\hline
\end{tabular}

the 25 th June (Fig. 8). Fluxes can reach high values of around $73 \mathrm{mg} \mathrm{m}^{-2} \mathrm{~h}^{-1}$. Isoprene normalised flux (at $30{ }^{\circ} \mathrm{C}, 1000 \mu \mathrm{mol} \mathrm{m} \mathrm{m}^{-2} \mathrm{~s}^{-1}$ ) is around $28.9 \mathrm{mg} \mathrm{m}^{-2} \mathrm{~h}^{-1}$.

For comparison, isoprene normalised flux values of 21.7 and $20.6 \mathrm{mg} \mathrm{m}^{-2} \mathrm{~h}^{-1}$ were found respectively during June and October 1995 above a $Q$. pubescens forest near Montpellier-France by Owen and Hewitt (2000).

\subsubsection{Fluxes from aerodynamic gradient method}

Isoprene fluxes were also determined by an aerodynamic gradient method (Section 2.2.2) for $06 / 25 / 2001$. Fig. 7 represents the volumic mixing ratio of isoprene at two levels $(12.5$ and $15 \mathrm{~m})$ and shows that the concentration difference is almost constant during the day even if it is slightly higher in the middle of the afternoon. Atmospheric mixing ratio above the canopy can reach a high value of about 10 ppbv. During the diurnal period, the measured friction velocity varies between 0.2 and $0.6 \mathrm{~m} \mathrm{~s}^{-1}$ and the stability parameter

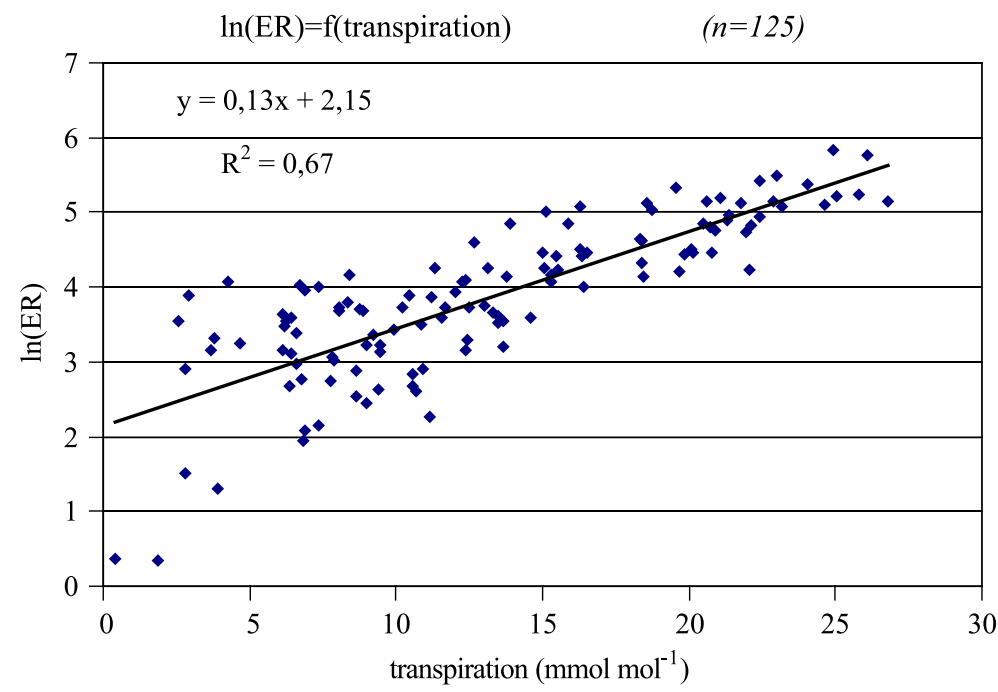

Fig. 6. Relation between transpiration/emission rates. 


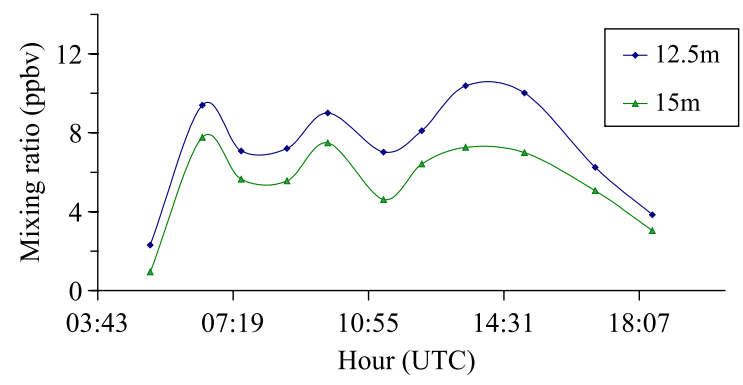

Fig. 7. Isoprene concentrations above the canopy (12.5 and $15 \mathrm{~m})$ (25th June 2001).

varies between -0.35 and -0.05 so we obtained a range of turbulent exchange coefficient ranging between 1.1 and $2.4 \mathrm{~m}^{2} \mathrm{~s}^{-1}$.

Fluxes determinated from the aerodynamic gradient method are also presented in Fig. 8. They reach maximal values of $55 \mathrm{mg} \mathrm{m}^{-2} \mathrm{~h}^{-1}$. The two methods give similar profile and maximun difference reaches a ratio of around 2 at midday.

\section{Conclusion}

This study shows the importance of $Q$. pubescens in term of isoprenic emissions. Emissions are mainly correlated to the foliar temperature and the PAR. The normalised emission rate found is $134.7 \mu \mathrm{g} \mathrm{g}_{\mathrm{DW}}{ }^{-1} \mathrm{~h}^{-1}\left(30{ }^{\circ} \mathrm{C}\right.$ and $\left.1000 \mu \mathrm{mol} \mathrm{m} \mathrm{m}^{-2} \mathrm{~s}^{-1}\right)$ and higher than the previous data quoted in bibliography. These differences can be related on the uncertainty of the cuvette method but also to the great variability of the emissions according to geographical, seasonal and genetic factors.

Fluxes can reach maximal values of $73 \mathrm{mg} \mathrm{m}^{-2} \mathrm{~h}^{-1}$. A maximal ratio of 2 was found between $Q$. pubescens emission fluxes estimating using the cuvette method and the aerodynamic gradient flux method. The daily variation of fluxes during 06/25/2001 is similar. The observed differences are explained by the relative large uncertainties associated with experimental and theoric steps resulting from flux measurements. $Q$. pubescens is one of the most important forest species of the Mediterranean area. Such emissions will contribute significantly to the emissions inventory of the Mediterranean area.

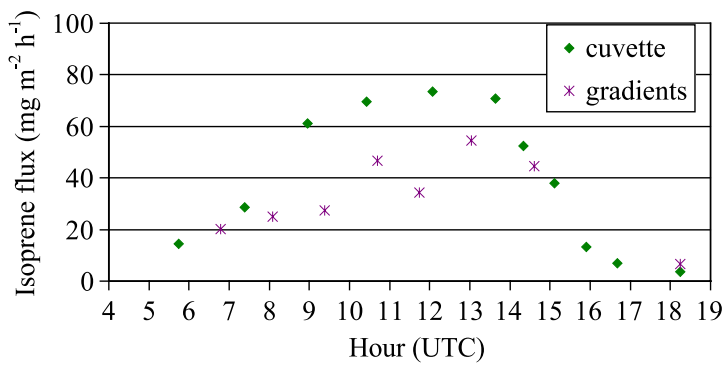

Fig. 8. Emission fluxes from the cuvette method and aerodynamic gradient method for the 25th June. 


\section{Acknowledgments}

We acknowledge CEMAGREF from Aix-en-Provence and the financial support by the ADEME (Agence de l'Environnement et de la Maîtrise de l'Energie-France).

\section{References}

Baldochi, D.D., Hicks, B.B., Mayers, T.P., 1988. Measuring biosphere-atmosphere exchanges of biologically related gases with micrometeorological method. Ecology 69, 1331-1340.

Businger, J.A., Wyngaard, J.C., Izumi, I., Bradley, E.F., 1971. Flux-profile relationships in the atmospheric surface layer. J. Atmos. Sci. 28, 181-189.

Ciccioli, P., Fabozzi, C., Brancaleoni, E., Cecinato, A., Frattoni, M., Cieslick, S., Kotzias, D., Seufert, G., Foster, P., Steinbrecher, R., 1997. Biogenic emissions from the Mediterranean pseudosteppe ecosystem present in Castelporziano. Atmos. Environ. 31 (S1), 167-175.

CORINAIR, 1999. Atmospheric Emission Inventory Guidebook, 2nd ed. European Environment Agency, pp. B9105-1-B1110-7.

Cros, B., Durand, P., Cachier, H., Drobinski, Ph., Fréjafon, E., Kottmeier, C., Perros, P.E., Ponche, J.-L., Robin, D., Said, F., Toupance, G., Wortham, H., 2004. The Escompte Program: an overview. Atmos. Res. 69 (3-4), $241-279$.

Darmais, S., Dutaur, L., Larsen, B., Cieslick, S., Luchetta, L., Simon, V., Torres, L., 2000. Emission flux of VOC by orange trees determined by both eddy accumulation and vertical gradient approaches. Chemosphere 2, 47-56.

Dumergues, L., 2003. Inventaire des émissions naturelles en région méditerranéenne: application à l'établissement de cadastres détaillés de la zone Marseille-Berre dans le cadre du projet ESCOMPTE. Détermination sur site de facteurs d'émission spécifiques à la zone d'étude. Thèse INPT Toulouse.

Dyer, A.J., Hicks, B.B., 1970. Flux-gradient relationship in the constant flux layer. Q. J. R. Meteorol. Soc. 96, $715-721$.

Fehsenfeld, F., Calvert, J., Fall, R., Goldan, P., Guenther, A., Hewitt, C.N., Lamb, B., Liu, S., Trainer, M., Westberg, H., Zimmerman, P., 1992. Emissions of volatile organic compounds from vegetation and the implications for atmospheric chemistry. Glob. Biogeochem. Cycles 6, 389-430.

Garland, J.A., 1974. Dry deposition of $\mathrm{SO}_{2}$ and other gases. Atmosphere-surface exchange of particulate and gaseous pollutants. Proceeding of symposium, September 4-6, Richland, Washington.

Guenther, A., Monson, R., Fall, R., 1991. Isoprene and monoterpene emission rate variability: observations with Eucalyptus and emission rate algorithm development. J. Geophys. Res. 96 (D6), 10799-10808.

Guenther, A., Zimmerman, P., Harley, P., Monson, R.K., Fall, R., 1993. Isoprene and monoterpene emission rate variability: Model evaluations and sensitivity analysis. J. Geophys. Res. 98 (D7), 12609-12617.

Kesselmeier, J., Schäfer, L., Ciccioli, P., Brancaleoni, E., Cecinato, A., Frattoni, M., Foster, P., Jacob, V., Denis, I., Fugit, J.L., Dutaur, L., Torres, L., 1996. Emission of monoterpenes and isoprene from a Mediterranean oak species Quercus ilex L. measured within the BEMA project. Atmos. Environ. 30, 1841-1850.

Kesselmeier, J., Bode, K., Müller, H., Schäfer, L., Wolf, A., Ciccioli, P., Brancaleoni, E., Cecinato, A., Frattoni, M., Foster, P., Ferrari, C., Jacob, V., Fugit, J.L., Dutaur, L., Simon, V., Torres, L., 1997. Emission of short chained organic acids, aldehydes and monoterpenes from Quercus ilex L. and Pinus pinea $L$. in relation to physiokogical activities, carbon budget and emission algorithms. Atmos. Environ. 31 (S1), 119-133.

Kesselmeier, J., Bode, K., Schäfer, L., Schebeske, G., Wolf, A., Brancaleoni, E., Cecinato, A., Ciccioli, P., Frattoni, M., Dutaur, L., Fugit, J.L., Simon, V., Torres, L., 1998. Simultaneous field measurements of terpene and isoprene emissions from two dominant Mediterranean oak species in relation to a north American species. Atmos. Environ. 32 (11), 1947-1953.

Kim, J.C., 2001. Factors controlling natural VOC emissions in a Southeastern US pine forest. Atmos. Environ. $35,3279-3292$.

Larsen, B., et al., 1997. Sampling and analysis of terpenes in air. An interlaboratory comparison. Atmos. Environ. 31 (S1), 35-50. 
Luchetta, L., 1999, Caractérisation et quantification dans la basse atmosphère de composés organiques volatils biogéniques et anthropiques contribuant à la pollution de l'air. Thèse INPT Toulouse, no. 214.

Monin, S.A., Obukhov, A.M., 1954. Dimensionless characteristics of turbulence in the surface layer. Akad. Nauk SSSR Goefiz, Inst Tr., $163-187$.

Monson, R.K., Jaeger, C.H., Adams, W.W., Driggers, E.M., Silver, G.M., Fall, R., 1992. Relationships among isoprene emission rate, photosynthesis and synthase activity as influenced by temperature. Plant Physiol. 98, $1175-1180$.

Monteith, J.L., Unsworth, M.H., 1990. Principles of Environmental Physics. Edward Arnold Publ., London.

Owen, S.M., Hewitt, C.N., 2000. Extrapoling branch enclosure measurements to estimates of regional scale biogenic VOC fluxes in the northwestern Mediterranean basin. J. Geophys. Res. 105 (D9), $11573-11583$.

Owen, S.M., Boissard, C., Street, R.A., Duckham, S.C., Csiky, O., Hewitt, C.N., 1997. Screening of 18 Mediterranean plant species for volatile organic compound emissions. Atmos. Environ. 31 (S1), $101-117$.

Owen, S.M., Boissard, C., Hafgenlocher, B., Hewitt, C.N., 1998. Field studies of isoprene emissions from vegetation in the Northwest Mediterranean region. J. Geophys. Res. 103 (D19), 25499-25511.

Owen, S.M., Boissard, C., Hewitt, C.N., 2001. Volatile organic compounds (VOCs) emitted from 40 Mediterranean plant species: VOC speciation and extrapolation to habitat scale. Atmos. Environ. 35 , 5393-5409.

Pier, P.A., McDuffie Jr., C., 1997. Seasonal isoprene emission rates and model comparisons using whole-tree emissions from white oak. J. Geophys. Res. 102 (D20), 23963-23971.

Sabillon, D., Cremades, L.V., 2001. Diurnal and seasonal variation of monoterpene emission rates for two typical Mediterranean species (Pinus pinea and Quercus ilex) from field measurements-relationship with temperature and PAR. Atmos. Environ. 35, 4419-4431.

Schäfer, L., Kesselmeier, J., Helas, G., 1992. Formic and acetic acid emission from conifers measured with a cuvette technique. In: Angelleti, G., Beilke, S., Slanina, J. (Eds.), Field Measurements and Interpretation of Species Related to Photooxydants and Acid Deposition, CEC Air Pollution Research, vol. 39. E. Guyot SA, Brussels, pp. 319-323.

Schnitzler, J.-P., et al., 1997. Seasonal pattern of isoprene synthase activity in Quercus robur leaves and its significance for modeling isoprene emission rates. Bot. Acta 110, 240-243.

Schuh, G., Heiden, A.C., Hoffman, Th., Kahl, J., Rockel, P., Rudolph, J., Wildt, J., 1997. Emissions of volatile organic compounds from sunflower and beech: dependence on temperature and light intensity. J. Atmos. Chem. 27, 291-318.

Seufert, G., et al., 1997. An overview of the Castelporziano experiments. Atmos. Environ. 31 (S1), 5-18.

Shao, M., et al., 2001. Volatile organic compound emissions from Scots Pine: mechanisms and description by algorithms. J. Geophys. Res. 106 (D17), 20483-20491.

Simon, V., Clement, B., Riba, M.L., Torres, L., 1994. The Landes experiment: Monoterpenes emitted from the maritime pine. J. Geophys. Res. 99 (D8), 16501-16510.

Staudt, M., Seufert, G., 1995. Light-dependent emission of monoterpenes by Holm oak (Quercus ilex L). Naturwissenschaften 82, 89-92.

Staudt, M., Bertin, N., Hansen, U., Seufert, G., Ciccioli, P., Foster, P., Frenzel, B., Fugit, J.L., 1997. Seasonal and diurnal patterns of monoterpene emissions from Pinus pinea (L.) under field conditions. Atmos. Environ. 31 (S1), 145-156.

Staudt, M., Bertin, N., Frenzel, B., Seufert, G., 2000. Seasonal variation in amount and composition of monoterpenes emitted by Young Pinus pinea trees_implications for emission modeling. J. Atmos. Chem. 35, 77-99.

Steinbrecher, R., Schürmann, W., Schönwitz, R., Eichstädter, G., Ziegler, H., 1991. Volatile monoterpenes in a forest of spruce (Picea abies [L.] Karst.): sources and mechanisms of emission and behavior in the atmosphere. The Proceedings of Eurotrac Symposium, vol. 90, pp. 221-224.

Steinbrecher, R., Hauff, K., Rabong, R., Steinbrecher, J., 1997. Isoprenoid emission of oak species typical for the Mediterranean area source strength and controlling variables. Atmos. Environ. 31 (S1), 79-88.

Street, R.A., Owen, S., Duckham, S.C., Boissard, C., Hewitt, C.N., 1997. Effect of habitat and age on variations in volatile organic compound (VOC) emissions from Quercus ilex and Pinus pinea. Atmos. Environ. 31 (S1), 89-100. 
Stull, B.R., 1988. An Introduction to Boundary Layer Meteorology. Atmospheric Sciences Library, Kluwer Academic Publishers.

Tingey, D.T., Evans, R.C., Bates, E.H., Gumpertz, M.L., 1987. Isoprene emissions and photosynthesis tree ferns. The influence of light and temperature. Physiol. Plant. 69, 609-616.

Webb, E.K., 1970. Profile relationships; the log-linear range and extension to strong variability. Q. J. Royal Meteorol. Soc. 96, 67-90.

Yokouchi, Y., Ambe, Y., 1984. Factors affecting the emission of monoterpenes from red pine (Pinus densiflora). Plant Physiol. 75, 1009-1012. 